Sibo Chen* and Cary Wu

\title{
\#StopAsianHate: Understanding the Global Rise of Anti-Asian Racism from a Transcultural Communication Perspective
}

https://doi.org/10.1515/jtc-2021-2002

Published online November 12, 2021

Abstract: The rise of anti-Asian racism during the COVID-19 pandemic has been a global phenomenon. This article aims to develop a transcultural communication perspective to examine the global rise in anti-Asian violence. It discusses the intersection of global and local factors underlying the rise of anti-Asian racism in Canada, namely (1) the historical and ongoing impacts of settler colonialism (2) the flaws of Canadian multiculturalism, and (3) the insider/outsider dichotomy adopted by mass media's framing of the pandemic. By explicating these structural factors from a transcultural communication perspective, this article argues that politicized transcultural discussions on white supremacy are urgently needed for initiating constructive conversations over anti-Asian racism worldwide.

Keywords: anti-Asian racism, settler colonialism, transcultural communication

The alarming surge of anti-Asian racism during the COVID-19 pandemic-as demonstrated by the horrific tragedy of Atlanta shootings in March 2021-calls for scholarly discussions that attend to not only pandemic-related stigmatization and prejudice, but also the structural roots of racial hierarchy underlying Western countries' persistent xenophobic violence. In the United States, for instance, many agree that anti-Asian racism is deeply ingrained "a long, bloody history of dehumanizing Asian Americans" (Chang, 2021). The pandemic has triggered the resurgence of toxic, racialized "Yellow Peril" tropes that defame Asians as "an existential threat to the West, to liberal human rights, to the market economy, to the 'rules-based' order, to American primacy" (Luo, 2021).

Considering how anti-Asian violence has resonated with other forms of racism, its recent increase has been analyzed in relation to colonial legacies and institutionalized white supremacy in settler states like Canada and the United States

*Corresponding author: Sibo Chen, Ryerson University, Toronto, Canada, E-mail: sibo.chen@ryerson.ca

Cary Wu, York University, Toronto, Canada, E-mail: carywu@yorku.ca 
(Kashyap, 2020; Yu, 2021). In fact, the significant increases of hate crimes (e.g., verbal and even physical harassment) against people of Asian descent has been a global phenomenon (Lee, Tan, \& Ruppanner, 2021).

Largely overlooked, however, is the intersection of global and local factors underlying this concerning trend. Locally, anti-Asian racism is closely connected to each nation's unique history of racial violence as well as its contemporary practice of managing ethnocultural relationships. In Canada, for instance, multicultural policies have received criticism for failing to reduce racial violence and injustice. Globally, the persistence of white supremacy needs to be understood in relation to the shared colonial history of settler states including the United States, Canada, Australia, and New Zealand. Furthermore, white supremacy has prompted flourishing right-wing populism across Western countries. By fueling a nationalist political ideology that foments the distinction between "us" and "others" based on skin color, right-wing populism presents an essential factor contributing to the global rise of anti-Asian racism. There is also a need to consider how local cultures interact with global dynamics (e.g., global capitalism) in shaping the long standing anti-Asian and other forms of violence (Yu, 2021).

This article aims to develop a transcultural communication perspective for researching the alarming surge of anti-Asian racism during the COVID-19 pandemic. This paper analyzes how the above local and global factors manifest in Canada, thereby elaborating why the country fails to curb the "contagion" of antiAsian racism from a transcultural communication perspective. We argue that the rise of anti-Asian racism in Canada results from three structural factors. (1) Globally, Western countries continue to collectively neglect the historical and ongoing impacts of settler colonialism. (2) Locally, the Canadian government turns a blind eye to the flaws of its multiculturalism policies. (3) Globally, both domestic and international media tend to adopt a problematic insider/outsider dichotomy when reporting on the pandemic. By explicating these structural factors, this article advocates for politicized transcultural discussions on the "whiteness" of the Canadian settler state. Such discussions are urgently needed for initiating constructive conversations over anti-Asian racism. Below, this article's analysis begins with an overview of the transcultural communication perspective that we adopt.

\section{Transcultural Communication as a Research Perspective}

Although in academic literature the term "transcultural communication" is often used interchangeably with "cross-cultural communication" and "intercultural communication" (for some recent examples, see Chen, Zhang, \& Liu, 2020; Chen, Zhang, He, 
\& Zhang, 2020), it nonetheless presents a distinctive theoretical framework that emphasizes the transcendence of oversimplified "cultural variables" and cultural hybridity (Baker \& Sangiamchit, 2019; Ding, 2014; Hepp, 2009, 2015; Jiang \& Huang, 2009; Pennycook, 2007). The concept of "transculturation" was originally coined by Cuban anthropologist Fernando Ortiz (1995) to describe the different phases of cultural convergence and transition, notably the acquisition of another culture (acculturation), the loss or uprooting of a previous culture (deculturation), and the consequent creation of new cultural phenomena (neoculturation).

In line with Ortiz's analysis of cultural hybridity, transcultural communication can be defined as symbolic interactions "where interactants move through and across, rather than in-between, cultural and linguistic boundaries, thus, 'named' languages and cultures can no longer be taken for granted and in the process, borders become blurred, transgressed and transcended" (Baker \& Sangiamchit, 2019, p. 472). This definition opposes the idea of culture as static traits inherent to ethnicity and citizenship. It also problematizes the existence of intercultural communication principles that are applicable to various cross-cultural setting. Instead, a transcultural approach to communication between cultures pays special attention to the increasing prevalence of transnational connections, flexible citizenships, and global cultural flows under the influence of globalization (Ding, 2014).

The transcultural communication perspective has two important implications for theorizing media culture in today's highly globalized society. First, the conventional division between domestic and international news events is increasingly blurred in everyday media production. Second, communications within and across cultures need to be recognized as complex processes that involve constant borrowing, bending, and blending of linguistic and communicative codes (Pennycook, 2007). As a result, when analyzing prevalent media communications across national borders, "we have to be wary of conceptualizing certain cultural patterns in media communication as being characteristic of a nation" (Hepp, 2009, p. 2).

Despite the pervasiveness of transcultural communication, nationalist ideologies remain an influential factor in shaping public opinion. Consequently, the intersection of global cultural flows is not without confrontation. For example, public perceptions of global epidemics like COVID-19 inevitably meet the challenge of ethnocentrism, which not only fails to recognize how such unprecedented medical crises affect communities (especially marginalized ones) on multiple fronts (Horton, 2020), but also adopts a biased "global versus local" dichotomy to blame "outsiders" as culprits.

How to put into practice the above principles of transcultural communication? According to Andreas Hepp (2009, 2015), adding a transcultural dimension to the research of media culture requires the synthesis of three overlapping discursive 
fields: "as the consequence of globalization; as a component of a postcolonial critique; and as a methodological issue” (Hepp, 2015, p. 28).To begin with, globalization influences not only the mobility and connectivity of elites but also everyday lives of ordinary people. This trend has created a global public sphere, in which various levels of cultural hybridity at the social level are embedded. Understanding the depth, scope, and direction of such cultural hybridity requires transnational inquires that move beyond a territorial understanding of culture.

In addition, integrating post-colonial perspectives into transcultural communication research implies a conscious resistance to Eurocentric conceptualizations of culture, which tend to deem non-Western cultural practices as backward and barbaric. Post-colonial critiques are mainly motivated by two components: (1) a deconstruction of colonialism, especially its ideological legitimation of white dominance, and (2) a critical analysis of the long-lasting impact of colonial processes and structures on racial injustice and discrimination today. Accordingly, a postcolonial analysis of communications between cultures should begin by (1) recognizing the central role that power plays in the formation and change of transcultural relationships and (2) assessing whether there are uneven encounters between the powerful and the powerless (Chakravartty\& Zhao, 2008; Kraid, 2005).

Finally, the adoption of both global and post-colonial perspectives for transcultural communication research presents new methodological challenges related to "methodological nationalism", the idea that many sociological theories build upon the assumption that national societies and territorial states were synonymous (Smith, 1979). Concerning this subject, Robins' (2006) critical comments based on his research on media and migration are especially illuminating. He argues that although the nation-state era is not over yet, analyzing the world as societies divided along the lines of nation-states falls short in explicating the reciprocal relationship between national and transnational dynamics. Instead, Robins recommends that transcultural research needs to be especially attentive to how communicative connectivity transcends state borders.

Echoing Hepp's theoretical framework, Ding (2014) considers transculturality as central to her analysis of global discourses on the 2002-2004 SARS outbreak. She criticizes traditional approaches such as intercultural communication, contrastive rhetoric, and comparative rhetoric since their "focus on nation-states as the unit of analysis seriously restricts their analytical capacity to engage with rhetorical and communicative practices in a transcultural context" (Ding, 2014, p. 14). To reveal transnational connections during a global pandemic in their full complexity, she calls for in-depth investigation into "interactions between localities at various levels and the larger cultural and economic global flows" (Ding, 2014, p. 22).

Inspired by Appadurai's (1990) emphasis on the contextual, heuristic, and comparative dimensions of individual cultures, Ding conceives pandemic-related 
power struggles between individuals, communities, and institutions as manifesting five interconnected dimensions: ethnoscapes, technoscapes, financescapes, mediascapes, and ideoscapes. According to this conceptual framework, confrontations in ethnoscapes (the flow of people across boundaries), mediascapes (the flow of media content across borders), and ideoscapes (the flow of grand narratives) are of significant relevance to the surge of anti-Asian racism during the ongoing COVID-19 pandemic.

How may theoretical insights offered by transcultural communication help us to understand toxic structural factors underlying the recent increase of anti-Asian hate crimes along with the COVID-19 pandemic? In what follows, we highlight three major subversive structural factors, beginning with colonial legacies and institutionalized White supremacy in many Western countries.

\section{Anti-Asian Racism in a Transcultural Perspective}

\subsection{Settler Colonialism and Racial Hierarchy}

First and foremost, the surge of anti-Asian racism and other forms of racial discrimination should be analyzed in relation to historical and current settler colonialism. According to American historian Shoemaker (2015), settler colonialism denotes a process of foreign intrusion and domination in which "large numbers of settlers claim land and become the majority". In a settler colonial state like Canada, this ongoing process entails a dynamic triangulation of Indigenous, settler, and alien populations: (1) a logic of elimination functions to make the state "white" through the decimation of Indigenous populations, and (2) a logic of exclusion serves to keep the state "white" through immigrant exploitation and racial exclusion.

To justify the ongoing theft of indigenous land for profit, settler colonialism embraces racially hierarchical narratives that legitimize white settlers' dominance over First Nations and other ethnic minorities. As a result, media narratives tend to deem Indigenous communities as trapped in perpetual suffering of social and economic hardship, rarely acknowledging the long-lasting damage colonial policies have done to these native communities. During the initial months of the "Idle No More" movement, for instance, Canadian print media produced considerable critiques against Indigenous activists and their settler allies, which, by framing Indigenous-led civil obedience as irrational and wrongly motivated, implicitly indicated Canadian settler colonialism as a historical past instead of present-day reality (Chen, 2018). 
Like First Nations, ethnic minorities are subject to a racial hierarchy set by settler colonialism. There are three parallel processes sustaining the reproduction of this hierarchy: Indigenous elimination, anti-Black racism, and immigrant exploitation (Kashyap, 2020). Overseas Asians and Asian Americans coming to Canada have been targeted by strategies of immigrant exploitation and exclusion throughout the Canadian history. Although early Asian migrants such as early Chinese immigrants arrived before Canada became a state, they had never been fully accepted as Canadians.

Instead, from as early as the era of transcontinental railroad building which relied on the cheap labor of Chinese workers, Asian immigrants have been a vulnerable labor force whose existence was purposefully controlled at the border. Limiting Asian immigration began in 1885 with the imposition of a head tax on Chinese migrants. The Komagata Maru incident excluding immigrants from India later in 1914 also illustrates that white Canadians wanted Canada to be "a white man's country”. Between 1895 and 1950, there were more than 175 anti-Asian laws in Canada, most notably, the Chinese Exclusion Act (1923) and the Internment Act to persecute Japanese Canadians during World War II (1942). These racist immigration policies were central to defining who was a "citizen" and who was a "foreigner". They were created to assure white domination.

Today, Canada's immigrant policies, despite their improvement, continue to exploit Asian Canadians and immigrants. They are often abstracted as economic expressions of alien capital all in the interests of white (re)settlement. Currently, Canada runs a "Start-Up Visa" program aiming at attracting selected, privileged groups such as wealthy migrants and those with foreign capital investment. In sharp contrast, the racialized temporary migrant labor programs such as migrant live-in caregiver program (predominantly Filipina women), admit migrant workers into the country to perform labor deemed unattractive yet necessary for the wellbeing of Canadian citizens. These migrant workers often remain within a few, lower-skilled occupations when they switch jobs, even after receiving legal permanent resident status.

Therefore, the current surge of anti-Asian racism in Canada reveals the inconvenient truth that Asians, even after raising multiple generations here, are still seen as "perpetual foreigners" and the embodiment of the "Yellow Peril" threat. Even the "model minority" myth, which presents a seemingly positive stereotype, distorts the realities of many working-class Asians' daily lives (Lee-An \& Chen, 2021). By portraying Asians as hard-working, independent, intelligent, and economically prosperous, this myth denies the socio-economic, political, and educational barriers faced by Asian Canadians and Asian Americans.

As poet and essayist Cathy Park Hong argues, the persistence of the model minority myth in the public mind puts Asians in a tough spot in North America's 
racial hierarchy: "Neither Black nor White, Asians are simultaneously stereotyped as model minorities and perpetual foreigners, and thus used as a wedge between Black and white people" (Ome, 2021). Indeed, if we trace how the myth emerged in public discourse, it becomes evident that the initial advocacy of Asians being the 'model' over other minorities occurred during the 1960s when the Civil Rights movement struggled for the equal rights of African Americans (Chun, 2020). This is hardly a mere coincidence.

Not only is Canadian mainstream media culture largely amnesiac about the above historical facts, its tolerance and indifference to anti-Asian sentiment have played a crucial role in nurturing violence like the Atlanta shootings.

\subsection{The Flaws of Canadian Multiculturalism}

In Canada, racial issues are often discussed under the concept "multiculturalism", which can be understood as "a feel-good celebration of ethno-cultural diversity, encouraging citizens to acknowledge and embrace the panoply of customs, traditions, music and cuisine that exist in a multiethnic society" (Kymlicka, 2010, p. 98). To the Canadian society, multiculturalism is a demographic fact, a national policy, as well as an ideology (Berry, 2013). It is a demographic fact since Canada is the most multicultural country with the highest percentage of foreign-born citizens in the world. This country of immigration is a society of mixed races, languages, cultures, religions, and more.

In 1971, Prime Minister Pierre Trudeau announced multiculturalism as an official government policy. Under this policy, ethnic groups are granted the right to preserve and develop their own cultures within Canadian society so as to promote public respect for ethno-cultural diversity. Overtime, multiculturalism has also become an ideology and been integrated into part of Canada's national identity. Today, most Canadians take pride in multiculturalism. Indeed, a recent survey shows that over 70 percent of Canadians hold a positive view toward multiculturalism (Canseco, 2020).

In recent decades, however, Canadian multiculturalism has been increasingly criticized for its inherent flaws (Benhabib, 2002; Kymlicka, 2015; Phillips, 2009). While celebrating inclusion and accommodation, this policy has largely failed to address the widespread racial and ethnic disparities in Canadian society (Herry, Rees, \& Tator, 2010; Simpson, James, \& Mack, 2011). This is because multiculturalism ignores the harsh reality of the widespread economic and political inequalities in Canadian society. Accommodating cultural distinctiveness and diversity alone will not solve the inequalities but instead exacerbate power inequalities between the majority and the minority groups. 
Indeed, multicultural practices often result in labor market discrimination and downward mobility of immigrants. Pakistani women in Toronto, for instance, must sometimes suitably display their cultural distinctiveness and at other times learn how to dress and act in a way to conform to the culture of the dominant group to navigate the job market (Ameeriar, 2012). Another telling example is the Canadian Seasonal Agricultural Workers Program, which, as Perry (2012, p. 189) argues, presents "a relic of Canada's racist and colonial past, one that continues uninterrupted in the present age of statist multiculturalism”. By regulating the rights and freedoms of an ongoing flow of temporary non-citizens, the program allows the Canadian state to simultaneously maintain its moral superiority and construct an invisible racial hierarchy exploiting foreign temporary workers.

Canada's "management" of ethno-cultural diversity through multiculturalism also fails to control racism against ethno-racial minorities (Henry, 2002). Although many Canadians see multiculturalism as a symbol of Canadian identity, those who feel that immigration levels are too high also represent a considerable proportion of the Canadian population. A recent survey has revealed that while most Canadians agree that diversity is a defining characteristic of Canada, they also believe that too many minority groups are seeking special treatment and they blame immigrants for not adopting “Canadian values”, whatever they are (Scotti, 2018). In fact, Canadian multiculturalism has provided a tacit basis for discrimination and racial violence. Below, we outline three major reasons for why its flaws contribute to the rise of anti-Asian racism.

First, promoting multiculturalism as Canada's national identity has allowed Canadians to ignore the harsh realities of many minorities and to refute the claim that racism is alive and well in the country. Denying its existence allows racism to fester and persist. This contributes not only to the rise of anti-Asian racism during the COVID-19 pandemic, but also to the lack of interest in discussing racism against Asians or simply Canadian racism. As a result, when Asians encounter racism, they are oftentimes forced to put up with it, not knowing who to turn for help and how to cope with it.

Second, multiculturalism serves as an institutional mechanism that protects whites from social interaction with visible minorities. It has led to the creation of segregated racial and ethno-cultural enclaves (Simpson et al., 2011). Thus far, multiculturalism has only served to maintain the status quo, allowing for the preservation of the cultural hegemony of the dominant cultural group. Indeed, after half a century of practice, visible minority groups are still invisible and the English, and to a lesser extent, the French, have continued to play a central role in defining Canadian society and culture (Henry \& Tator, 2006). Anti-Asian racism is integrally tied to the fact that Asian Canadians continue to be segregated socially, economically, and politically in Canada. 
Third, multiculturalism tends to neglect the fact that cultures are not static but can be constantly updated and adapted. By foregrounding the idea of culture as the property of an ethnic group or race, it reinforces the othering process that perceives minorities as eternally distinctive and different. According to Phillips (2009, p. 14), multiculturalism "exaggerates the internal unity of cultures, solidifies differences that are currently more fluid, and makes people from other cultures seem more exotic and distinct than they really are". By dividing people into ethnic boxes and using the boxes to highlight their distinctiveness and define their needs and rights, multiculturalism policies also run the risk of contributing to intergroup competition and threat. The aforementioned "model minority" myth, for instance, purports the erroneous view that systemic racism against Asians does not exist since they have 'succeeded' in Canada. It also ignores the tremendous heterogeneity and diversity within the broader Asian Canadian population, which is made up of a multitude of ethnicities, cultures, languages, and immigration experiences. By constructing Asians as the answer to racial and economic challenges, as the model race, as the deserving other, the established racial hierarchy also uses Asians to justify the ongoing racism toward black and indigenous people.

\subsection{The Return of "Yellow Peril"}

Having reviewed both global and local factors contributing to anti-Asian racism in Canada, we now turn to the Canadian media sphere where global and local discourses meet. Media framing of the COVID-19 pandemic plays an important role in mediating public expressions of prejudice and xenophobia. Recent analyses of pandemic related news coverage such as Bolsen, Palm, and Kingsland (2020), Calvillo, Ross, Garcia, Smelter, and Rutchick (2020), and Dhanani and Franz (2021) have collectively demonstrated that when media stories emphasize the pandemic's severe economic and social impacts or wrongfully accuse the connection between COVID-19 and China, people reading them are more likely to express negative attitudes toward Asians and to hold the belief that resources should be prioritized for citizens instead of immigrants.

These analyses are also sharply critical of right-wing media outlets' repeated reference of COVID-19 as either "the China virus" or "the Chinese virus". Dhanani and Franz (2021), for instance, argue that linking the virus to the country reporting it for the first time presents a problematic adoption of stigmatizing language that intentionally seeks to stoke up criticisms of Chinese cultural practices, skepticism of the Chinese government, and sensationalized depictions of Chinese food outlets. From a socialpsychological perspective, people's tendency to connect outgroups with the threat of 
contracting a disease or illness roots in an adaptive and self-protective response (Faulkner, Schaller, Park, \& Duncan, 2004).Consequently, framing techniques that foreground the connection between COVID-19 and foreigners reinforce existing biases against outgroups, thereby increasing prejudicial responses.

Therefore, the "insider versus outsider" dichotomy, by implicitly framing Asian communities as a threat to Western society and culture, has provoked socially entrenched racism and xenophobia (Le, Cha, Han, \& Tseng, 2020; Wang et al., 2020). In addition, its frequent appearances in North America's COVID-19 coverage have contributed significantly to the return of "Yellow Peril" tropes in public discourse (Calvillo et al., 2020; Chun, 2020; Luo, 2021).

Indeed, the associations between disease, racism, and Asian Americans are hardly new in North America. The stigmatization and "othering" of people of Asian descent follows a historically recurring process that tends to be amplified and replicated "when widespread fear of catching disease engenders prejudice against groups that are different from the majority population, positioning them as effective scapegoats" (Gover, Harper, \& Langton, 2020, p. 661).

The alarming return of "Yellow Peril" tropes manifests itself on both institutional and individual levels (Elias, Ben, Mansouri, \& Paradies, 2021; Roberto, Johnson, \& Rauhaus, 2020). On the institutional level, government policies such as elevated tax burdens, education and housing segregation, barriers to citizenship (Gover et al., 2020) further sustain racial inequalities. On the individual level, research has identified people's leaning toward "white Christian nationalism" as a powerful predictor of whether they deem bigoted exclusionary practices as acceptable. Hyped up by Trump and his supporters, white Christian nationalism functions as a proxy for political and religious conservatism, which wrongly "equates national belonging and membership with ethnocultural markers including race, nativity, and religious background” (Perry, Whitehead, \& Grubbs, 2020, p. 2). Under this kind of influence, racially dominant and well-established groups are more likely to perceive people of Asian descent as "foreigners" outside their place of belonging who threaten the "normality" of Western societies.

Notably, over the past few years, the prevalence of white nationalism in online disinformation has led to the concerning radicalization of certain segments of the general population who hold hostile attitudes toward Asian minorities even before the current pandemic (Marwick \& Lewis, 2017). According to Davey, Hart, and Guerin (2020, p. 40) in their recent analysis of right-wing extremist activists across mainstream and alternative social media platforms, "attacks on and discussion of the Muslim community, immigrants and Justin Trudeau are particularly salient to right-wing extremism actors". Nonetheless, more alarming is the trend that "rightwing extremists in Canada" are getting used to conveying hateful narratives in 
implicit ways, "becoming adept at treading the fine line around what is permissible within the terms of service for social media platforms" (Davey et al., 2020, p. 40).

This means that underlying a seemingly peaceful atmosphere could be quietly growing racial tensions. Right-wing extremism covertly spreading via social media platforms is a major contributor to pandemic-fueled racism, which recently has transformed the city of Vancouver into "North America's anti-Asian hate crime capital" (Pearson, 2021).

In sum, the escalation of socio-political conflicts, worsened by the ongoing pandemic and sharpened by Donald Trump's inflammatory rhetoric, is undeniably responsible for the loss of lives caused by anti-Asian hate crimes. Current Canadian mainstream media culture, however, has largely failed to respond to the attacks by right-wing extremism and white supremacy.

\section{Discussion: Politicizing Transcultural Communication}

In the above discussion we focus on the Canadian context to explicate three structural factors underlying the alarming surge of anti-Asian racist incidents during the COVID-19 pandemic. The presence of these factors raises the urgent question: What can be done to address anti-Asian racism and other systemic racisms and foster a culture of inclusion and belonging? In our view, a first step toward achieving such goals is to initiate transcultural conversations on politicized challenges around diversity, equity, and inclusion (EDI).

In consultation with theoretical insights offered by previous research such as Ding (2014) and Hepp (2009, 2015), our proposal of initiating such transcultural conversations aims to discuss the following questions by considering the communicative interweaving brought by gender, racial, national, and class differences:

1. How to counter systemic racism across public institutions? This requires continuing discussions on (1) established policies that create "glass ceiling" negatively impacting minorities as well as (2) measures to hold politicians accountable for their inflammatory rhetoric.

2. How to debunk the "model minority" myth? Given the myth's prevalence in popular discourse, there is an urgent need for concerted efforts to reveal its marginalization of Asian communities in many socio-political discussions.

3. How to build a united front between Asian communities and other ethnic groups suffering from systemic racism? There have been heated discussions on some Asians belonging to the upper middle class who have been unwilling to show support for social movements like "Idle No More" and "Black Lives 
Matter”. Such spilt within minorities' calls for innovative communication strategies aiming at public mobilization and coalition building.

4. Concerning Canada's ongoing settler colonialism, how could Asian communities contribute to policy discussions on reconciliation and future directions of Canadian multiculturalism? There has been growing public consensus on the necessity of transformative changes in Canada's Settler-Indigenous relations. Asian communities, with their socio-cultural experiences, would make meaningful contributions to relevant public deliberation.

5. Racial injustice issues are often "socio-economic inequalities in disguise". There is no denial that the gap between rich and poor is widening not only between Caucasian families and Asian families, but also within Asian communities. This worrisome trend brings the tough question of redistribution of income and wealth. The pursuit of EDI goals would not be sustainable if not backed by economic measures.

This tentative list of questions and solutions also points to the fact that the current surge of anti-Asian racism is a multilayered, translocal phenomenon that can only be dealt with by transcultural solidarity and joint efforts through both top-down and bottom-up approaches.

\section{References}

Ameeriar, L. (2012). The sanitized sensorium. American Anthropologist, 114(3), 509-520.

Appadurai, A. (1990). Disjuncture and difference in the global cultural economy. Public Culture, 2(2), 1-24.

Baker, W., \& Sangiamchit, C. (2019). Transcultural communication: Language, communication and culture through English as a lingua franca in a social network community. Language and Intercultural Communication, 19(6), 471-487.

Benhabib, S. (2002). The claims of culture: Equality and diversity in the global era. Princeton, $\mathrm{NJ}$ : Princeton University Press.

Berry, J. W. (2013). Research on multiculturalism in Canada. International Journal of Intercultural Relations, 37(6), 663-675.

Bolsen, T., Palm, R., \& Kingsland, J. T. (2020). Framing the origins of COVID-19. Science Communication, 42(5), 562-585.

Calvillo, D. P., Ross, B. J., Garcia, R. J. B., Smelter, T. J., \& Rutchick, A. M. (2020). Political ideology predicts perceptions of the threat of COVID-19 (and susceptibility to fake news about it). Social Psychological and Personality Science, 11(8), 1119-1128.

Canseco, M. (2020). Canadians take more pride in multiculturalism, less in economy this year. The Outlook. Retrieved from https://www.theoutlook.ca/canadians-take-more-pride-inmulticulturalism-less-in-economy-this-year-1.24162592. 
Chakravartty, P., \& Zhao, Y. (Eds.). (2008). Global communications: Toward a transcultural political economy (critical media studies: Institutions, politics, and culture). Lanham, MD: Rowman \& Littlefield Publishers.

Chang, J. (2021). The long history of violence against Asian Americans that led up to Atlanta. Washington Post. Retrieved from https://www.washingtonpost.com/outlook/2021/03/22/ atlanta-shooting-history-asians/.

Chen, S. (2018). How to discredit a social movement: Negative framing of "Idle No More" in Canadian print media. Environmental Communication, 13(2), 144-151.

Chen, J. A., Zhang, E., \& Liu, C. H. (2020a). Potential impact of COVID-19-related racial discrimination on the health of Asian Americans. American Journal of Public Health, 110(11), 1624-1627.

Chen, L., Zhang, D., He, Y., \& Zhang, G. (2020b). Transcultural political communication from the perspective of proximization theory: A comparative analysis on the corpuses of the Sino-US trade war. Discourse \& Communication, 14(4), 341-361.

Chun, C. W. (2020). The return of the 'Yellow Peril.' Language. Culture and Society, 2(2), 252-259.

Davey, J., Hart, M., \& Guerin, C. (2020). An online environmental scan of right-wing extremism in Canada: Interim report. In J. Birdwell (Ed.), Institute for Strategic Dialogue. Retrieved from https://www.isdglobal.org/wp-content/uploads/2020/06/An-Online-Environmental-Scanof-Right-wing-Extremism-in-Canada-ISD.pdf.

Dhanani, L. Y., \& Franz, B. (2021). Why public health framing matters: An experimental study of the effects of COVID-19 framing on prejudice and xenophobia in the United States. Social Science \& Medicine, 269, 113572.

Ding, H. (2014). Rhetoric of a global epidemic: Transcultural communication about SARS. Carbondale, IL: Southern Illinois University Press.

Elias, A., Ben, J., Mansouri, F., \& Paradies, Y. (2021). Racism and nationalism during and beyond the COVID-19 pandemic. Ethnic and Racial Studies, 44(5), 783-793.

Faulkner, J., Schaller, M., Park, J. H., \& Duncan, L. A. (2004). Evolved disease-avoidance mechanisms and contemporary xenophobic attitudes. Group Processes \& Intergroup Relations, 7(4), 333-353.

Gover, A. R., Harper, S. B., \& Langton, L. (2020). Anti-Asian hate crime during the COVID-19 pandemic: Exploring the reproduction of inequality. American Journal of Criminal Justice, 45(4), 647-667.

Henry, F. (2002). Canada's contribution to the "management" of ethno-cultural diversity. Canadian Journal of Communication, 27(2). https://doi.org/10.22230/cjc.2002v27n2a1297.

Henry, F., \& Tator, C. (2006). Racial profiling in Canada: Challenging the myth of "a few bad apples". Toronto, $\mathrm{ON}$ : University of Toronto Press.

Hepp, A. (2009). Transculturality as a perspective: Researching media cultures comparatively. Forum: Qualitative Social Research, 10(1). https://doi.org/10.17169/fqs-10.1.1221.

Hepp, A. (2015). Transcultural communication. Malden, MA: Wiley-Blackwell.

Herry, F., Rees, T., \& Tator, C. (2010). The colour of democracy: Racism in Canadian Society (4th ed.). Toronto, ON: Nelson Education.

Horton, R. (2020). Offline: COVID-19 is not a pandemic. The Lancet, 396(10255), 874.

Jiang, F., \& Huang, K. (2009). Differences among inter, cross, trans-cultural communication and next step for intercultural communication study. Journalism and Communication (China), 16(6), 53-63. 
Kashyap, M. B. (2020). U.S. settler colonialism, white supremacy, and the racially disparate impacts of COVID-19. California Law Review Online. Retrieved from https://www. californialawreview.org/settler-colonialism-white-supremacy-covid-19/.

Kraidy, M. M. (2005). Hybridity, or the cultural logic of globalization. Philadelphia, PA: Temple University Press.

Kymlicka, W. (2010). The rise and fall of multiculturalism? New debates on inclusion and accommodation in diverse societies. International Social Science Journal, 61(199), 97-112.

Kymlicka, W. (2015). The essentialist critique of multiculturalism: Theory, policies and ethos. In V. Uberoi, \& T. Modood (Eds.), Multiculturalism rethought: Interpretations, dilemmas and new directions (pp. 209-249). Edinburgh, UK: Edinburgh University Press.

Le, T. K., Cha, L., Han, H. R., \& Tseng, W. (2020). Anti-Asian xenophobia and Asian American COVID-19 disparities. American Journal of Public Health, 110(9), 1371-1373.

Lee-An, J., \& Chen, X. (2021). The model minority myth hides the racist and sexist violence experienced by Asian women. The Conversation Canada. Retrieved from https:// theconversation.com/the-model-minority-myth-hides-the-racist-and-sexist-violenceexperienced-by-asian-women-157667.

Lee, R., Tan, X., \& Ruppanner, L. (2021). Anti-Asian bias isn't just an American problem. Washington Post. Retrieved from https://www.washingtonpost.com/politics/2021/03/26/ anti-asian-bias-isnt-just-an-american-problem/.

Luo, N. (2021). The American victims of Washington's anti-China hysteria. The New Republic. Retrieved from https://newrepublic.com/article/162429/yellow-peril-rhetoric-selling-warwith-china.

Marwick, A., \& Lewis, B. (2017). Media manipulation and disinformation online. Data \& Society Research Institute. Retrieved from https://datasociety.net/library/media-manipulationanddisinfo-online.

Ome, M. (2021). Why this wave of anti-Asian racism feels different? The Atlantic. Retrieved from https://www.theatlantic.com/ideas/archive/2021/03/cathy-park-hong-anti-asian-racism/ $618310 /$.

Ortiz, F. (1995). Cuban counterpoint: Tobacco and sugar. Durham, NC: Duke University Press.

Pearson, N. O. (2021). This is why Vancouver has become North America's anti-Asian hate crime capital. The National Post. Retrieved from https://nationalpost.com/news/canada/this-iswhy-vancouver-has-become-north-americas-anti-asian-hate-crime-capital.

Pennycook, A. (2007). Global Englishes and transcultural flows. New York, NY: Routledge.

Perry, J. A. (2012). Barely legal: Racism and migrant farm labour in the context of Canadian multiculturalism. Citizenship Studies, 16(2), 189-201.

Perry, S. L., Whitehead, A. L., \& Grubbs, J. B. (2020). Prejudice and pandemic in the Promised Land: How white Christian nationalism shapes Americans' racist and xenophobic views of COVID-19. Ethnic and Racial Studies, 44(5), 759-772.

Phillips, A. (2009). Multiculturalism without culture. Princeton, NJ: Princeton University Press.

Roberto, K. J., Johnson, A. F., \& Rauhaus, B. M. (2020). Stigmatization and prejudice during the COVID-19 pandemic. Administrative Theory \& Praxis, 42(3), 364-378.

Robins, K. (2006). Towards a transcultural policy for European cosmopolitanism. In U. H. Meinhof, \& A. Triandafyllidou (Eds.), Transcultural Europe: Cultural policy in a changing Europe (pp. 254-284). London, UK: Palgrave Macmillan.

Scotti, M. (2018). Canadians love diversity, just not the change that comes with it: Survey. Global News. Retrieved from https://globalnews.ca/news/4288791/diversity-immigration-canadamixed-feelings-survey/. 
Shoemaker, N. (2015). A typology of colonialism. Perspectives on History. Retrieved from https:// www.historians.org/publications-and-directories/perspectives-on-history/october-2015/atypology-of-colonialism.

Simpson, J. S., James, C. E., \& Mack, J. (2011). Multiculturalism, colonialism, and racialization: Conceptual starting points. Review of Education, Pedagogy, and Cultural Studies, 33(4), 285-305.

Smith, A. D. (1979). Nationalism in the twentieth century. Oxford, UK: Oxford University Press.

Wang, S., Chen, X., Li, Y., Luu, C., Yan, R., \& Madrisotti, F. (2020). 'I'm more afraid of racism than of the virus!': Racism awareness and resistance among Chinese migrants and their descendants in France during the Covid-19 pandemic. European Societies, 23(sup 1), S721-S742.

$\mathrm{Yu}, \mathrm{H}$. (2021). The white elephant in the room: anti-Asian racism in Canada. Beyond: People, Ideas and Actions for a Better World. Retrieved from https://beyond.ubc.ca/henry-yu-whiteelephant/. 